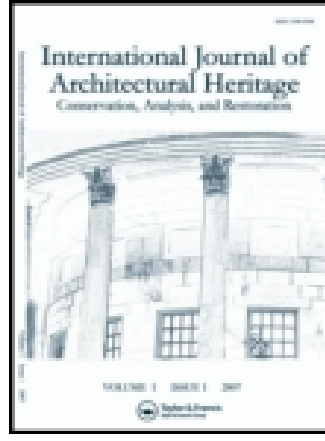

International Journal of Architectural Heritage

Conservation, Analysis, and Restoration

ISSN: 1558-3058 (Print) 1558-3066 (Online) Journal homepage: http://www.tandfonline.com/loi/uarc20

\title{
Empirical Formulation for Estimating the Fundamental Frequency of Slender Masonry Structures
}

\section{Manjip Shakya, Humberto Varum, Romeu Vicente \& Aníbal Costa}

To cite this article: Manjip Shakya, Humberto Varum, Romeu Vicente \& Aníbal Costa (2016) Empirical Formulation for Estimating the Fundamental Frequency of Slender Masonry Structures, International Journal of Architectural Heritage, 10:1, 55-66, DOI: 10.1080/15583058.2014.951796

To link to this article: http://dx.doi.org/10.1080/15583058.2014.951796

Accepted author version posted online: 21

Nov 2014.

Published online: 21 Nov 2014.

Submit your article to this journal $\pi$

山 Article views: 171

View related articles

View Crossmark data $\asymp$

Citing articles: 1 View citing articles $ک$ 


\title{
Empirical Formulation for Estimating the Fundamental Frequency of Slender Masonry Structures
}

\author{
Manjip Shakya, Humberto Varum, Romeu Vicente, and Aníbal Costa (1) \\ University of Aveiro, Department of Civil Engineering, Campus Universitário de Santiago, Aveiro, Portugal
}

\begin{abstract}
The fundamental frequency of a structure enables better assessment of its seismic demand for an efficient design and planning of its maintenance and retrofit strategy. The frequency is independent of the type of external loads, however, depends on structural stiffness, mass, damping and boundary conditions. In the case of slender masonry structures such as towers, minarets chimneys, and pagoda temples, it is influenced by mass and stiffness distribution, connection to adjacent structures, material properties, aspect ratio and slenderness ratio. In this present article, the data collected from various literature reviews on the slender masonry structures regarding dynamic, geometrical, and mechanical characteristics have been correlated to identify the major parameters influencing the fundamental frequency of such structures. The database has been used for developing an empirical formulation for predicting the fundamental frequency of such structures. The comparison between the experimental fundamental frequencies and the estimated fundamental frequencies are carried out in order to define reliability and accuracy of these empirical formulae.
\end{abstract}

\section{ARTICLE HISTORY}

Received 3 February 2014

Accepted 5 June 2014

\section{KEYWORDS}

Slender structure; empirical

formula; fundamental

frequency; experimental

frequency; correlation

\section{Research aims}

The fundamental frequency plays a primary role in the assessment of the seismic vulnerability of slender structures. It can be evaluated by numerical analysis, or even by using empirical formulation provided in buildings codes. In the case of slender masonry structures, reliable results are required from the numerical model analysis for precisely calibrating the interventions work, but systematic studies focused on this issue are still missing. In this article, a literature review has been carried out in order to collect data regarding the dynamic properties and the material and geometric characteristics of slender masonry structures. The compiled database has been analyzed and correlated to develop an empirical formulation for predicting the fundamental frequency of such structures.

\section{Introduction}

The dynamic identification of a structure is important to define its structural health status, after damage generated by an earthquake (Buffarini et al. 2011). Strong damage or complete loss of structures forming part of the architectural heritage when subjected to strong earthquake ground motion has occurred throughout the history of humanity. The behavior of slender masonry structures under seismic loading is generally dominated by the axial stresses that arise from the static vertical loads combined with the dynamic loading induced by the low-intensity earthquakes that is often close to the compression strength of the traditional masonry material and also makes them more vulnerable to base settlements (Salvatore et al. 2003). Moreover, during strong earthquakes, tensile damage is distributed along the height of the structure, while shear damage is concentrated in the lower section (Casolo and Pena 2007). Thus, such structures have long been considered to be particularly susceptible to seismic actions and therefore, it is crucial to understand the dynamic behavior of these structures to preserve and strengthen them against earthquake excitation.

The knowledge of dynamic properties, together with site seismicity and stratigraphy, is the starting point for an accurate estimation of the seismic safety of these structures (Ferraioli et al. 2011). A reliable evaluation of the dynamic properties of a structure is of importance for the analysis of its dynamic behavior, in particular under seismic actions (Rainieri and Fabbrocin 2011). Generally, mechanical and semi-analytical models are used to estimate the dynamic properties of built

CONTACT Manjip Shakya manjip.shakya@ua.pt Doctoral Student, University of Aveiro, Department of Civil Engineering, Campus Universitário de Santiago, 3810-193 Aveiro, Portugal.

Color versions of one or more of the figures in the article can be found online at http://www.tandfonline.com/uarc.

(๑) 2016 Taylor \& Francis 
structures (Bennati et al. 2005b; Krstevska et al. 2010a). In this article, database regarding the dynamic properties and material and geometric characteristics of slender masonry structures are correlated to propose some empirical formulations. The proposed empirical formulations are capable of efficiently predicting the fundamental frequency of such structures.

\subsection{Damage of slender masonry structures in past earthquakes}

Strong damage or complete loss suffered by the cultural patrimony when subjected to considerable earthquake ground motion has been occurring throughout the history of humanity. The historical slender masonry structures have been found during the past to be susceptible to damage, and prone to partial or total collapse, under earthquake actions, due to the lack of inadequate retrofit (Russo et al. 2010). A detailed analysis of the documentation regarding the damages caused by past Italian earthquakes (Corradi et al. 2002; Lermitte et al. 2011) allows drawing interesting conclusions on the qualitative behavior of such structures when they are subjected to seismic action. In particular, the following issues can be considered as relevant:

- For isolated towers, damage patterns are frequently distributed along the whole height, although they are usually more severe at the base section (Buffarini et al. 2011);

- During strong earthquakes, vertical shear cracks are sometimes observed. In this case, the reduction of the cross-section stiffness during the deformation process may have a key role on the overall response of the structure (Casolo et al. 2012);

- It can be argued that the damage evolution during a dynamic excitation plays a crucial role in reducing the resisting geometry of the structure, thus activating higher vibration modes which seem to be associated with the damage of the upper sections, especially the tower crown (Curti et al. 2006; Milani et al. 2012).

Curti et al. (2008) observed in 31 Italian bell towers damaged by the 1976 Friuli earthquakes that the belfry is the most vulnerable part of the tower due to the presence of large openings leading to slender pillars with elevated top masses, as well as in the case of towers which are contiguous to churches at different heights creating horizontal constraints that increase the seismic vulnerability of the tower by limiting its slenderness and by creating localized stiffening zones that could lead to concentration of high stresses.

The work by Firat (2001) has shown that the location of the failure in the minarets that collapsed during 1999 Kocaeli and Duzce earthquakes (Turkey) was near bottom of the minarets, where a transition was made from a circular to squared section. The old masonry minarets were also observed to fail near the bottom of the cylinder section, where the minaret connects to the adjacent building or is part of it at the lower section (Dogangun et al. 2008). Few cases of minor damage were also observed, such as the collapse of parts of the balcony during the Kocaeli earthquake (Oliveira et al. 2012).

\section{Database collection and analysis}

Slender masonry structures (Figure 1) can be characterized by their distinguished architectural characteristics, age of construction and original function, but their comparable geometric and structural ratios yield to the definition of an autonomous structural type. These structures are characterized by their notable slenderness and also represent one of the main differences from most of the historic structures or even ordinary buildings Sepe et al. (2008). These structures are scattered over different countries with different densities and features. Database of such structures was compiled through a systematic literature review. Data were acquired from experimental works performed on the determination of dynamic properties and material characteristics.

Table 1 summarize the database that comprises 59 slender masonry structures, among them 32 are towers, 16 are minarets, seven are chimneys, and four are Pagoda temples. The database summarizes the geometric characteristics of slender masonry structures along with theirs dynamic properties. The database information regarding geometric characteristics indicates the total height of the structures ranging from $10 \mathrm{~m}$ (shortest) to $74.4 \mathrm{~m}$ (tallest) and the width of the wall at the base varying from $1.96 \mathrm{~m}$ (minimum) to 14 $\mathrm{m}$ (maximum). Moreover, the minimum slenderness, which is considered as the height to minimum breadth at base ratio, ranges from 1.66 (minimum) to 15.67 (maximum).

The database information regarding dynamic properties shows the frequencies of the reviewed structures. It is noticeable in the database that the fundamental frequency of slender masonry structures is highly influenced by height of the structure and slenderness ration (i.e., the taller the structure the lower the fundamental frequency and similarly higher 

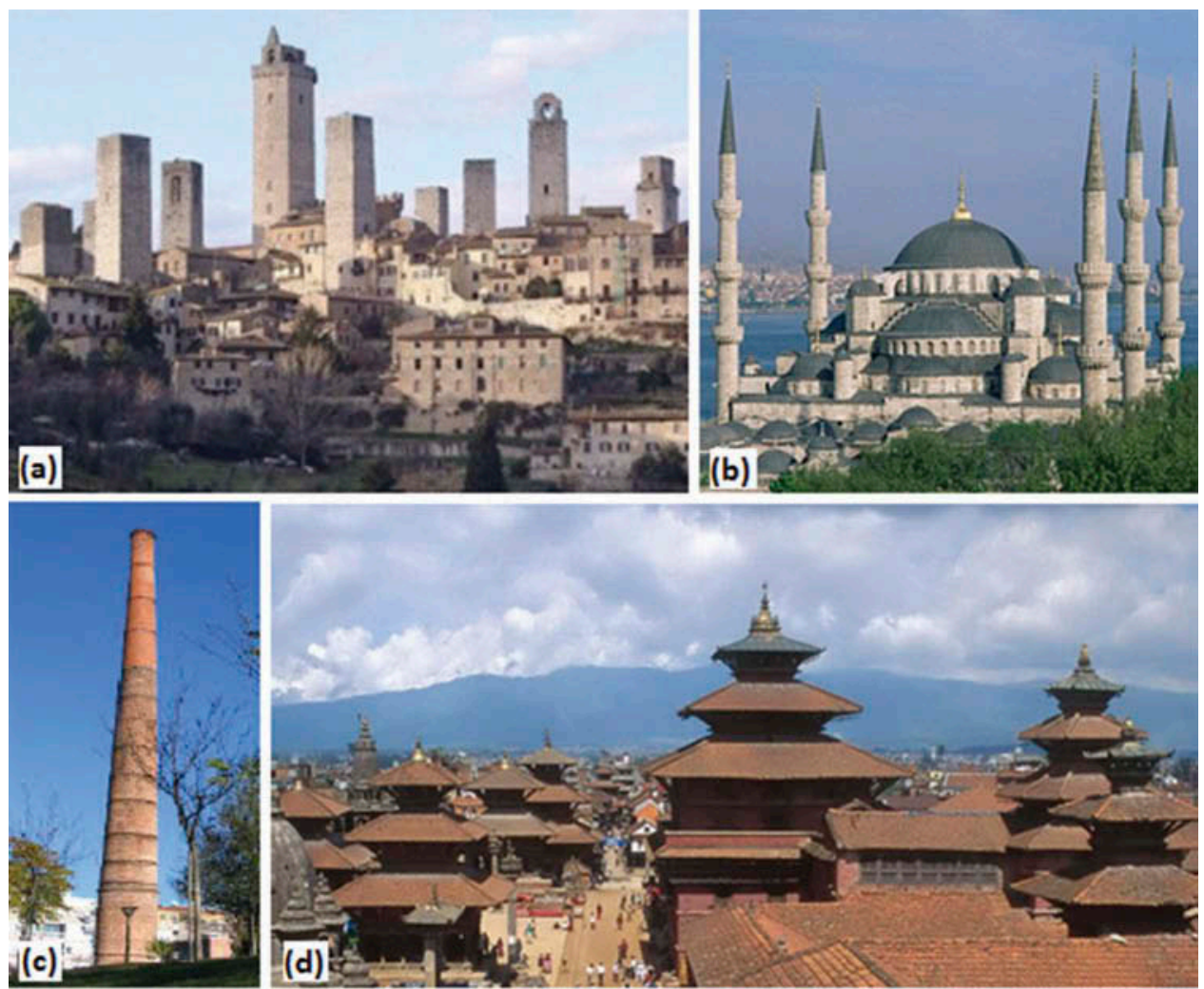

Figure 1. Slender masonry structures: (a) Towers, (b) minarets, (c) chimney, and (d) pagoda temples.

the slenderness ratio lower the fundamental frequency). The database reveals that the tower structures have third mode shape as torsion. All the experimental frequencies for various slender masonry structures presented here in the database are measured by different authors using the ambient vibration test. The knowledge of Eigen-frequencies of bell towers is of great relevance for the analysis of their dynamic response under bell excitation (Bennati et al. 2005a). However, in the proposed methodology this type of effect is not considered). Much less information is available regarding dynamic properties of chimneys and pagoda temples.

\section{Formulation for computing the fundamental frequency/period of tower and cantilever structures}

The empirical formulation proposed for the prediction of fundamental period/frequency for bell tower/cantilever structures by different codes and authors are taken as a basis for developing new empirical formulae for such structures. Later, the predictive performance between previous author's formulations and newly developed formulation are compared with reference to the experimental fundamental frequency.
A linear relation between the fundamental vibration period $\left(T_{1}\right)$ and the height $(H)$ of the tower proposed by Faccio et al. (2009) is:

$$
T_{1}=0.0187 \mathrm{H}
$$

The formulation in Equation (1) better fits the experimental data, for slender structures with a periods lower than $1 \mathrm{sec}$; however, it slightly underestimates the period higher than $1 \mathrm{sec}$ (Rainieri and Fabbrocin 2011).

An empirical correlation for the prediction of the natural period $\left(T_{1}\right)$ of Italian masonry towers as a function of height $(H)$ has been proposed by Rainieri and Fabbrocin (2011):

$$
T_{1}=0.01137 H^{1.138}
$$

Equation (2) leads to an overestimation for low values of the natural period and to an underestimation at the higher values of the natural period (Rainieri and Fabbrocin 2011).

From Equation (3), proposed by the Spanish Standard NCSE-02 (Norma de Construcciòn Sismorresistente [NSCE] 2002), the value of the estimated fundamental frequency of towers $\left(f_{1}\right)$ can be obtained by:

$$
f_{1}=\frac{\sqrt{L}}{0.06 \sqrt{\frac{H}{2 L+H}}}
$$


Table 1. Database compiled from the literature review.

\begin{tabular}{|c|c|c|c|c|c|c|}
\hline Reference & $\begin{array}{c}\text { Type of } \\
\text { structure }\end{array}$ & Type of masonry & $\begin{array}{c}\text { Total height, } \\
\mathrm{H}(\mathrm{m})\end{array}$ & $\begin{array}{l}\text { Min. breadth at } \\
\text { base, B (m) }\end{array}$ & $\begin{array}{c}\text { Slenderness, } \\
\text { H/B }\end{array}$ & $\begin{array}{c}\text { Experimental natural } \\
\text { frequency }(\mathrm{Hz})\end{array}$ \\
\hline Bongiovanni et al. (2000) & Tower & Brick masonry & 18.50 & 3 & 6.17 & 2.43 \\
\hline Camata et al. (2008) & Tower & Stone masonry & 19 & 5.40 & 3.52 & 3.78 \\
\hline Carone et al. (2013) & Tower & Brick masonry & 20 & 3.5 & 5.71 & 2.63 \\
\hline Ramos et al. (2010) & Tower & Stone masonry & 20.40 & 4.50 & 4.53 & 2.56 \\
\hline Tomaszewska (2010) & Tower & - & 22.65 & 7.70 & 2.94 & 1.42 \\
\hline Bayraktar et al. (2009) & Tower & Stone masonry & 23 & 5 & 4.60 & 2.59 \\
\hline Bonato et al. (2000) & Tower & - & 26 & 3.50 & 7.43 & 1.66 \\
\hline Sepe et al. (2008) & Tower & Brick masonry & 28 & 8.20 & 3.41 & 2.40 \\
\hline Guerreiro and Azevedo (2001) & Tower & Stone masonry & 30 & 8 & 3.75 & 1.37 \\
\hline Pelella et al. (2001) & Tower & - & 30 & 4 & 7.50 & 1.95 \\
\hline Ceriott et al. (2009) & Tower & Stone masonry & 31 & 8 & 3.88 & 1.25 \\
\hline Foti et al. (2012) & Tower & Stone masonry & 34.7 & 4.11 & 8.44 & 4.57 \\
\hline Ivorra et al. (2010) & Tower & Brick masonry & 35.50 & 7 & 5.07 & 2.15 \\
\hline Gentile and Sais (2013) & Tower & Stone masonry & 36.72 & 5.70 & 6.44 & 1.21 \\
\hline Ivorra and Cervera (2001) & Tower & $\begin{array}{l}\text { Stone masonry + Brick } \\
\text { masonry }\end{array}$ & 37.19 & 4.68 & 7.95 & 0.73 \\
\hline Casciati and Al-Saleh (2010) & Tower & - & 39.24 & 5.96 & 6.58 & 1.05 \\
\hline Balduzzi et al. (2006) & Tower & $\begin{array}{l}\text { Stone masonry + Brick } \\
\text { masonry }\end{array}$ & 40 & 4 & 10 & 1.36 \\
\hline Ivorra and Pallares (2006) & Tower & Brick masonry & 41 & 5.60 & 7.32 & 1.29 \\
\hline Ferraioli et al. (2011) & Tower & $\begin{array}{l}\text { Stone masonry + Brick } \\
\text { masonry }\end{array}$ & 41 & 11.30 & 3.63 & 1.26 \\
\hline Peeters et al. (2011) & Tower & Stone masonry & 41 & 7 & 5.86 & 1.57 \\
\hline Kohan et al. (2011) & Tower & - & 41.40 & 7.60 & 5.45 & 1.37 \\
\hline D'Ambrisi et al. (2012) & Tower & Brick masonry & 41.80 & 6 & 6.97 & 1.08 \\
\hline Buffarini et al. (2011) & Tower & Stone masonry & 43 & 6.50 & 6.62 & 1.48 \\
\hline Ferraioli et al. (2011) & Tower & Stone masonry & 45.50 & 14 & 3.25 & 1.05 \\
\hline Jaras et al. (2010) & Tower & $\begin{array}{l}\text { Stone masonry + Brick } \\
\text { masonry }\end{array}$ & 49.90 & 12.60 & 3.96 & 1.25 \\
\hline Costa (2011) & Tower & Stone masonry & 55 & 8 & 6.88 & 1.05 \\
\hline Diaferio et al. (2013) & Tower & Stone masonry & 57 & 7.5 & 7.6 & 2.04 \\
\hline Russo et al. (2010) & Tower & Brick masonry & 58 & 7.60 & 7.63 & 0.61 \\
\hline Bartoli et al. (2013) & Tower & $\begin{array}{l}\text { Stone masonry + Brick } \\
\text { masonry }\end{array}$ & 60 & 9.50 & 6.32 & 1.31 \\
\hline Ceroni et al. (2010) & Tower & $\begin{array}{l}\text { Stone masonry + Brick } \\
\text { masonry }\end{array}$ & 68 & 11 & 6.18 & 0.69 \\
\hline Gentile and Saisi (2007) & Tower & Brick masonry & 74 & 6 & 12.33 & 0.59 \\
\hline Pieraccini et al. (2009) & Tower & Stone masonry & 87.40 & 14.50 & 6.03 & 0.62 \\
\hline Zaki et al. (2008) & Minaret & Stone masonry & 20 & 3.40 & 5.88 & 1.84 \\
\hline Oliveira et al. (2012) & Minaret & Brick masonry & 23.02 & 3.73 & 6.17 & 1.68 \\
\hline El-Attar et al. (2005) & Minaret & Stone masonry & 24.48 & 3.80 & 6.44 & 1.95 \\
\hline Pau and Vestroni (2011) & Minaret & Stone masonry & 30 & 3.55 & 8.45 & 1.45 \\
\hline Oliveira et al. (2012) & Minaret & Brick masonry & 38.65 & 3.68 & 10.50 & 0.80 \\
\hline Turk and Cosgun (2012) & Minaret & Stone masonry & 40.25 & 3 & 13.42 & 0.88 \\
\hline Oliveira et al. (2012) & Minaret & Brick masonry & 41.60 & 3.97 & 10.48 & 1.37 \\
\hline Oliveira et al. (2012) & Minaret & Stone masonry & 44.96 & 5.28 & 8.52 & 1.03 \\
\hline Krstevska et al. (2010b) & Minaret & Stone masonry & 47 & 3 & 15.67 & 1.04 \\
\hline \multirow[t]{7}{*}{ Oliveira et al. (2012) } & Minaret & Brick masonry & 48.70 & 4.64 & 10.50 & 1.18 \\
\hline & Minaret & Brick masonry & 51.70 & 5.12 & 10.10 & 0.95 \\
\hline & Minaret & Stone masonry & 54.90 & 4.80 & 11.44 & 0.63 \\
\hline & Minaret & Brick masonry & 63.20 & 4.96 & 12.74 & 1.02 \\
\hline & Minaret & Brick masonry & 66.55 & 7.52 & 8.85 & 1.32 \\
\hline & Minaret & Brick masonry & 66.55 & 7.52 & 8.85 & 1.17 \\
\hline & Minaret & Brick masonry & 74.40 & 6.50 & 11.45 & 0.83 \\
\hline Aoki and Sabia (2004) & Chimney & Brick masonry & 15 & 1.96 & 7.65 & 2.69 \\
\hline Costa (2010) & Chimney & Brick masonry & 22.86 & 2.20 & 10.39 & 1.37 \\
\hline Yamamoto and Maeda (2008) & Chimney & Brick masonry & 23.10 & 2.34 & 9.87 & 1.00 \\
\hline Grande and Açores (2009) & Chimney & Stone masonry & 31 & 4.00 & 7.75 & 1.13 \\
\hline Eusani and Benedettini (2009) & Chimney & Brick masonry & 36 & 3.40 & 10.59 & 0.93 \\
\hline Lopes et al. (2009) & Chimney & Brick masonry & 41.40 & 3.70 & 11.19 & 0.61 \\
\hline Costa et al. (2011) & Chimney & Brick masonry & 45.60 & 4.30 & 10.60 & 0.79 \\
\hline Jaishi et al. (2003) & $\begin{array}{l}\text { Pagoda } \\
\text { temple }\end{array}$ & Brick masonry & 10 & 3 & 3.33 & 3.10 \\
\hline Shakya et al. (2014) & $\begin{array}{l}\text { Pagoda } \\
\text { temple }\end{array}$ & Brick masonry & 12.76 & 3.48 & 3.67 & 2.06 \\
\hline \multirow[t]{2}{*}{ Jaishi et al. (2003) } & Pagoda & Brick masonry & 16.93 & 10.20 & 1.66 & 2.32 \\
\hline & $\begin{array}{l}\text { Pagoda } \\
\text { temple }\end{array}$ & Brick masonry & 27 & 6.58 & 4.10 & 1.68 \\
\hline
\end{tabular}


where, $L$ is the plan dimension of the building in the direction of oscillation, $H$ is the height of tower.

Equation (3), leads to an overestimation for low values of the natural period and to an underestimation for higher values of the period (Rainieri and Fabbrocin 2011).

The first frequency of vibration $\left(f_{1}\right)$ for cantilever (Clough and Penzien 1993) is given by:

$$
f_{1}=\frac{1}{2 \pi}(1.875)^{2} \sqrt{\frac{E I}{\bar{m} L^{4}}}
$$

where, $E$ is the modulus of elasticity, $I$ the moment of inertia, $\bar{m}$ the mass per unit of length, and $L$ the total length of the cantilever.

\subsection{Empirical formulae for computing the fundamental frequency of slender masonry structures}

On the basis of previous formulations and compiled database, four new empirical formulations are developed for the reliable prediction of fundamental frequency of slender masonry structures. Each formulation is further expressed in three sub formulations depending upon different multiplication factors, for three different structures categories (i.e., all types of slender masonry structures, towers (e.g., bell tower, clock tower, civic tower, and minarets). Linear $\mathrm{R}$ squared approach is carried out to evaluate the predictive performance of these proposed empirical formulations.

On the basis of power correlation with the experimental fundamental frequency, the first formulation for predicting fundamental frequency $\left(f_{1}\right)$ is developed as a function of height $(H)$, which is presented in Equation (5).

$$
f_{1}=\frac{1}{\alpha H^{\beta}}
$$

where:

- $\alpha=0.0517$ and $\beta=0.76$ (for all types of slender masonry structures); with $\mathrm{R}$ squared value $=0.59$

- $\alpha=0.0151$ and $\beta=1.08$ (for masonry tower structures); with $\mathrm{R}$ squared value $=0.73$

- $\alpha=0.1178$ and $\beta=0.533$ (for masonry minaret structures); with $\mathrm{R}$ squared value $=0.59$

On the basis of Equation (3) formulation, here is suggested a second formulation (Equation (6)) for the prediction of the fundamental frequency $\left(f_{1}\right)$ of slender masonry structures as a function of the height $(H)$ and the lowest plan width base dimension at base $(W)$ :

$$
f_{1}=\frac{(W)^{\varphi}}{C H\left(\frac{H}{W+H}\right)^{\delta}}
$$

where,

- $C=0.038, \varphi=0.25$ and $\delta=1$ (for all types of slender masonry structures); with R squared value $=0.89$

- $C=0.03, \varphi=0.17$ and $\delta=0.5$ (for all masonry tower structures); with $\mathrm{R}$ squared value $=0.96$

- $C=0.1, \varphi=1$ and $\delta=1$ (for all masonry minaret structures); with $\mathrm{R}$ squared value $=0.46$.

Retaining the basic structures of Equation (4), where fundamental frequency of a slender structure is expected to be a function of the second moment of area $(I)$, height of the structures $(H)$, young's modulus of elasticity $(E)$ and the mass per unit of length $(\bar{m})$, a third formulation (Equation (7)) for the prediction of the fundamental frequency $\left(f_{1}\right)$ of slender masonry structures is proposed accounting for all these parameters.

$$
f_{1}=\frac{1}{2 \pi}(1.875)^{2} \sqrt{\frac{X E I}{\bar{m} H^{4}}}
$$

where,

- $\mathrm{X}=1.425$ (for all types of slender masonry structures); with $\mathrm{R}$ squared value $=0.56$

- $\mathrm{X}=1.375$ (for all masonry tower structures); with $\mathrm{R}$ squared value $=0.48$

- $\mathrm{X}=1.345$ (for all masonry minaret structures); with $\mathrm{R}$ squared value $=0.89$

On the basis of power correlation with the experimental fundamental frequency, the formulation for predicting fundamental frequency $\left(f_{1}\right)$ is developed as a function of minimum slenderness ratio, i.e., height $(H)$ to minimum breadth at base ratio $(B)$, which is presented in Equation (5).

$$
f_{1}=Y\left(\frac{H}{B}\right)^{-z}
$$

where,

- $Y=3.648$ and $\mathrm{z}=0.55$ (for all types of slender masonry structures); with $\mathrm{R}$ squared value $=0.33$

- $Y=3.58$ and $\mathrm{z}=0.57$ (for masonry tower structures); with $\mathrm{R}$ squared value $=0.20$

- $Y=8.03$ and $z=0.86$ (for masonry minaret structures); with $\mathrm{R}$ squared value $=0.58$ 
Here, the newly developed formulations expressed in Equation (5), Equation (6), and Equation (8) are basically function of geometrical characteristics whereas Equation (7) is the function of both geometrical and mechanical characteristics. These formulations have been compared with experimental database and previous formulations by other authors for validation.

\section{Predictive performance compared and results}

The fundamental frequency predicted by the proposed empirical formulations (i.e., Equations [5-7] is compared with previous authors' estimation and also with the experimental fundamental frequency. Moreover, predictive performance of proposed sub-formulations for various types of slender masonry structures is also compared for validation of their reliability.

Figure 2 illustrates the comparison between the experimental and empirical fundamental frequency expressed according to different predictive formulations for all types of slender masonry structures. Results reveal that empirical formulation proposed by Faccio et al. (2009) and Rainieri and Fabbrocin (2011), leads to an overestimation of the fundamental frequency for slender structures of height between $15 \mathrm{~m}$ to $50 \mathrm{~m}$, while the values from Equation (5) better fit the experimental fundamental frequency.

Figure 3 illustrates the comparison of empirical fundamental frequency expressed by Equation (5) for different types of slender masonry structures. Results reveal that the fundamental frequency predicted by three different sub-formulations (i.e., for all types of slender masonry structures, towers and minarets) derived from Equation (5), using different numerical values for factor $\alpha$ and $\beta$, have different trendlines, which suggest, it is not reliable to estimate the fundamental frequency for all types of slender masonry structures using a single formulation. Therefore, for the better predictive performance, it is better to estimate using individual formulation presented in Equation (5).

Similarly, Figure 4 illustrates the comparison between experimental and empirical fundamental frequency expressed according to NCSE-02 (2002) and Equation (6). Results show that empirical formulation proposed by NCSE-02 (2002), leads to an underestimation of fundamental frequency for the slender masonry structures $15 \mathrm{~m}$ to $40 \mathrm{~m}$ height, while the values from Equation (6) formulation better fit the experimental fundamental frequency.

Result of the comparison between empirical fundamental frequencies expressed by Equation (6) for different types of slender masonry structures is shown in Figure 5. Here, the result reveals that the fundamental frequency predicted by three different sub-formulations (i.e., for all types of slender masonry structures, towers and minarets) derived from Equation (6), using different numerical values for factor $c, \gamma$ and $\delta$, have a similar trendline, which suggests that it is reliable to estimate fundamental frequency for all types of slender masonry structures including towers with the same formulation. However, results also show that sub-formulation derived from Equation (6) for the minarets has a different trendline than others, which means that for the better predictive performance, it is better to estimate the fundamental frequency of minaret structures using different formulation presented in Equation (6).

Lastly, Figure 6 illustrates the comparison between experimental and fundamental frequency expressed according Equation (4) and Equation (7). Results show that formulation proposed in Equation (4), leads to an underestimation of fundamental frequency, while the values from Equation (7) formulation better fit the experimental fundamental frequency.

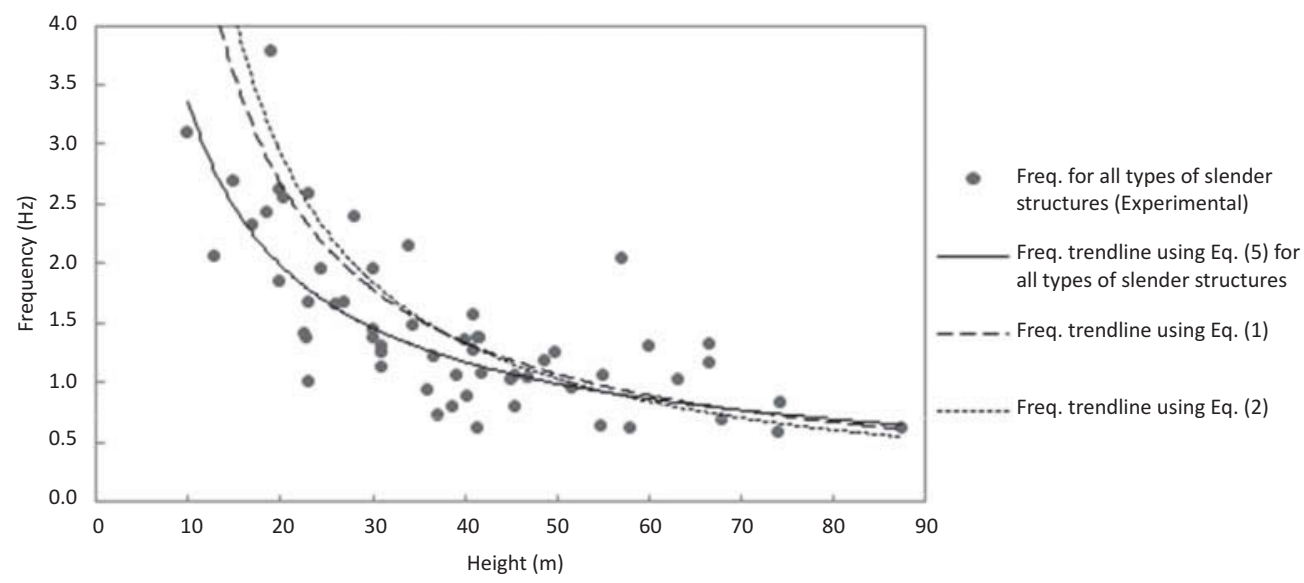

Figure 2. Comparison between experimental and predicted values of the fundamental frequency of slender masonry structures according to different formulation. 


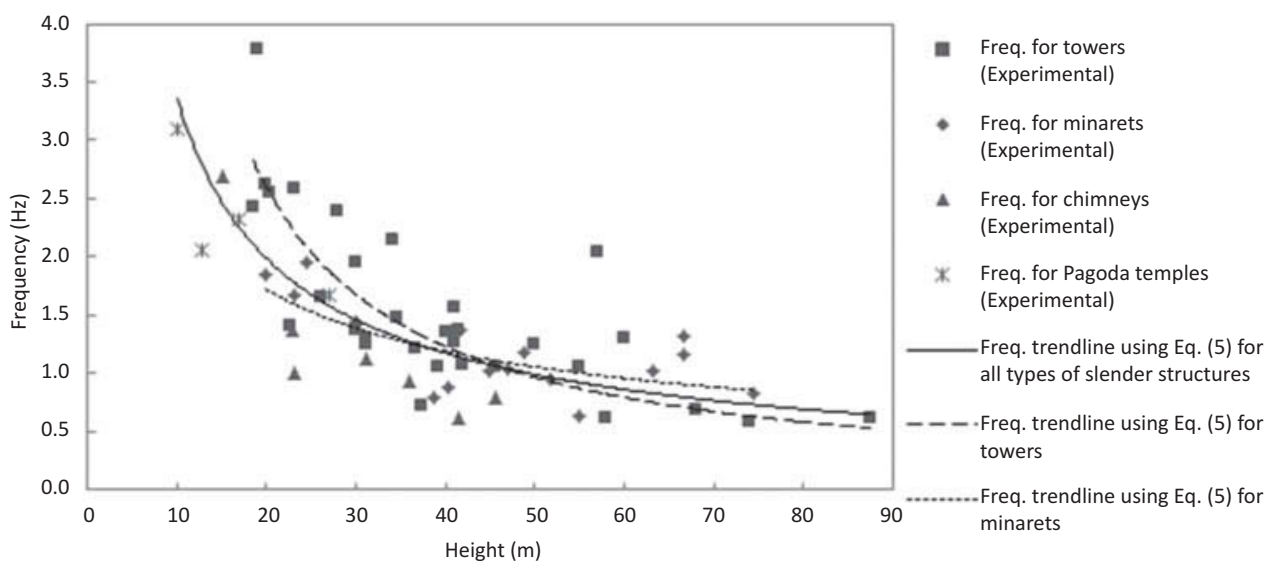

Figure 3. Comparison of the fundamental frequencies predicted by three different sub-formulations of Equation (5) for all types of slender masonry structures, towers, and minarets.

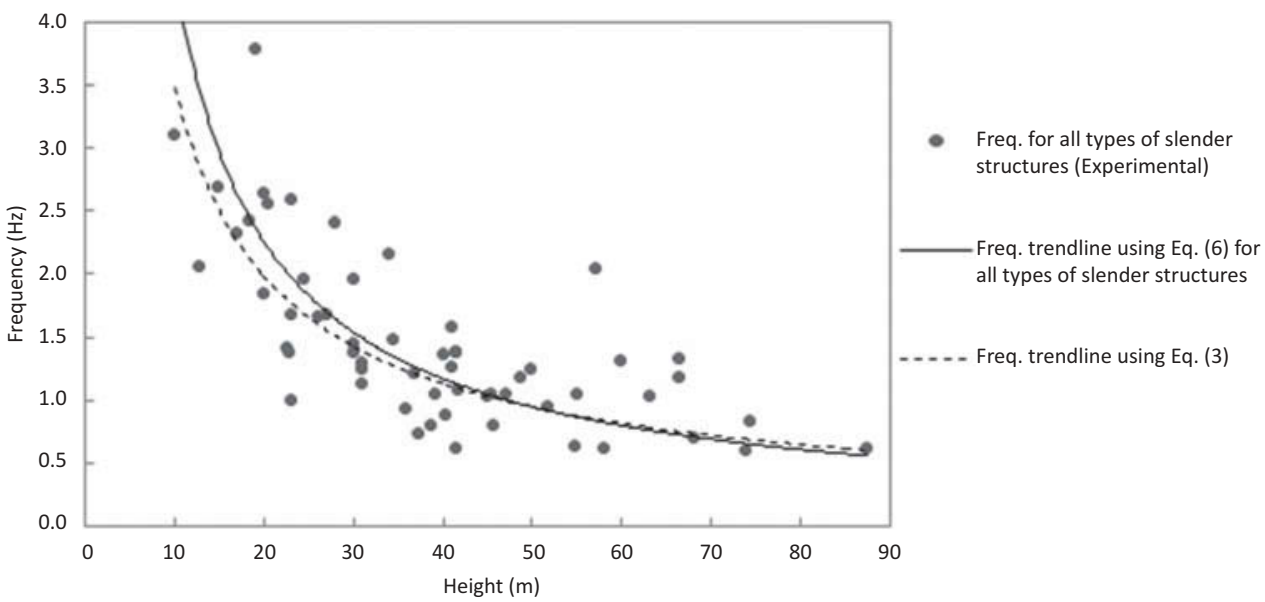

Figure 4. Comparison between experimental and predicted values of the fundamental frequency according to Equation (3) and Equation (6) for all types of slender structures.

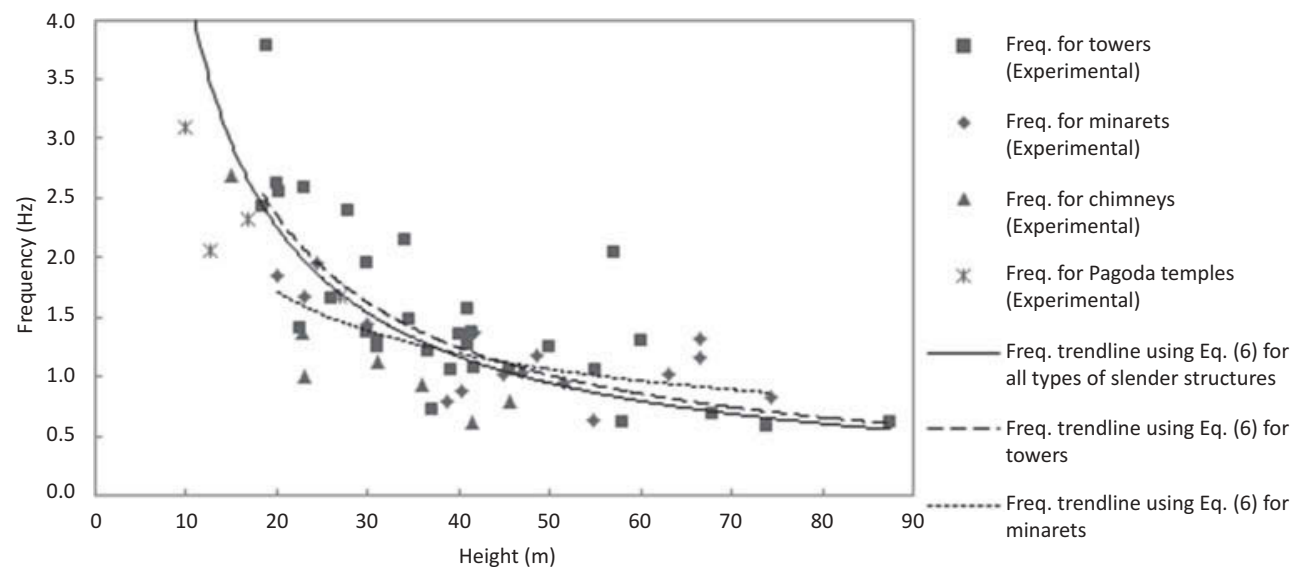

Figure 5. Comparison of the fundamental frequencies predicted by three different sub-formulations of Equation (6) for all types of slender masonry structures, towers, and minarets.

Figure 7 illustrates the comparison of empirical fundamental frequency expressed by Equation (7) for different types of slender masonry structures. Result reveals that the fundamental frequency predicted by three different sub-formulations (i.e., for all types of slender masonry structures, towers and minarets) derived from Equation (7), using different numerical values for factor $x$, have similar trendlines, which 


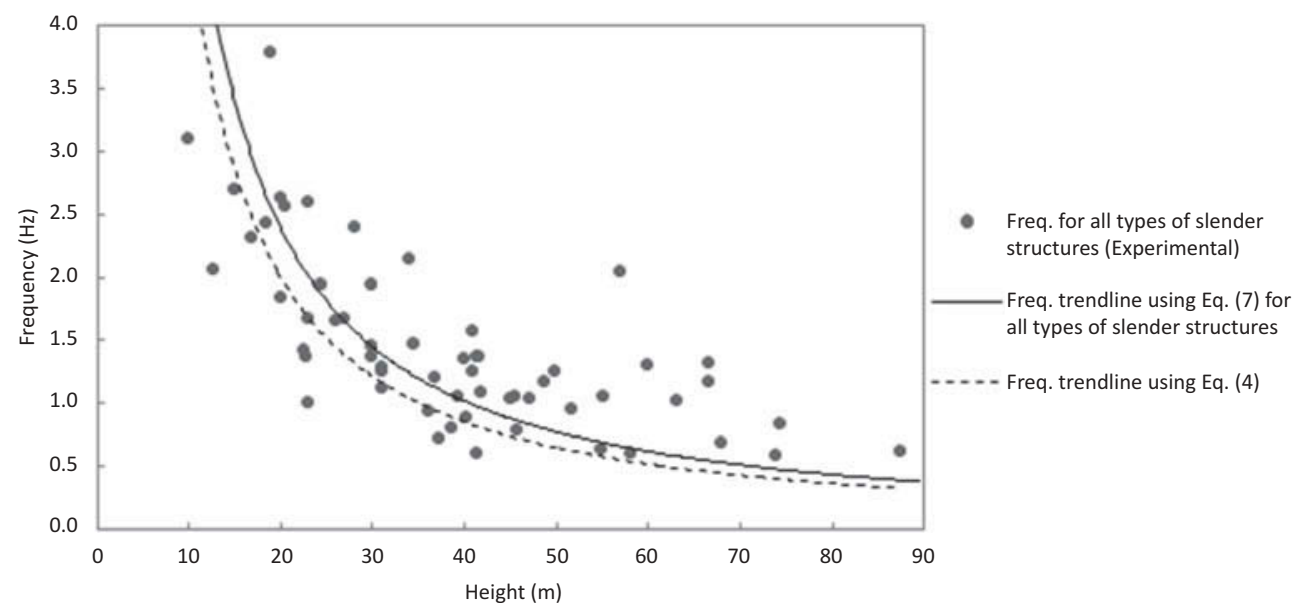

Figure 6. Comparison between experimental and predicted values of the fundamental frequency according to Equation (4) and Equation (7) for all types of slender structures.

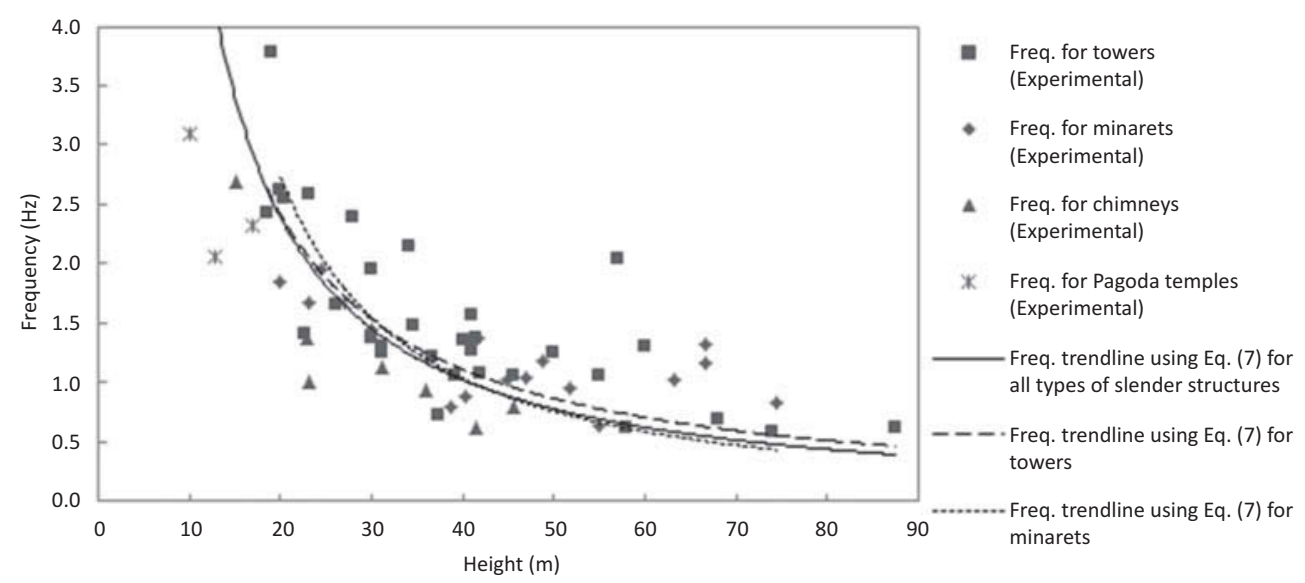

Figure 7. Comparison of the fundamental frequencies predicted by three different sub-formulations of Equation (7) for all types of slender masonry structures, towers and minarets.

suggest that it is reliable to estimate the fundamental frequency for all types of slender masonry structures including towers and minarets resourcing to a single formulation. But, for the better predictive performance, it is better to estimate using individual formulation presented in Equation (7).

Figure 8 illustrates the comparison between experimental and empirical fundamental frequency expressed according Equation (8) for all types of slender masonry structures. Results show that an empirical formulation proposed, lead to better fit the experimental fundamental frequency.

Figure 9 illustrates the comparison of empirical fundamental frequency expressed by Equation (8) for different types of slender masonry structures. Result reveals that the fundamental frequency predicted by three different sub-formulations (i.e., for all types of slender masonry structures, towers and minarets) derived from Equation (8), using different numerical values for factor $Y$ and $\mathrm{z}$, have a similar trendline, which suggest that it is reliable to estimate fundamental frequency for all types of slender masonry structures including towers with the same formulation. However, results also show that sub-formulation derived from Equation (8) for the minarets has a different trendline than others, which means that for the better predictive performance, it is better to estimate the fundamental frequency of minaret structures using different formulation presented in Equation (8). Among all of four empirical formulation proposed, Equation (6) has the highest linear R squared value, which obviously is the best predictive performance formulation for all types of slender masonry structures.

\section{Conclusion}

In this article the database compiled is the key constituent in the calibration of empirical formulations for the prediction of the fundamental frequency for slender masonry 


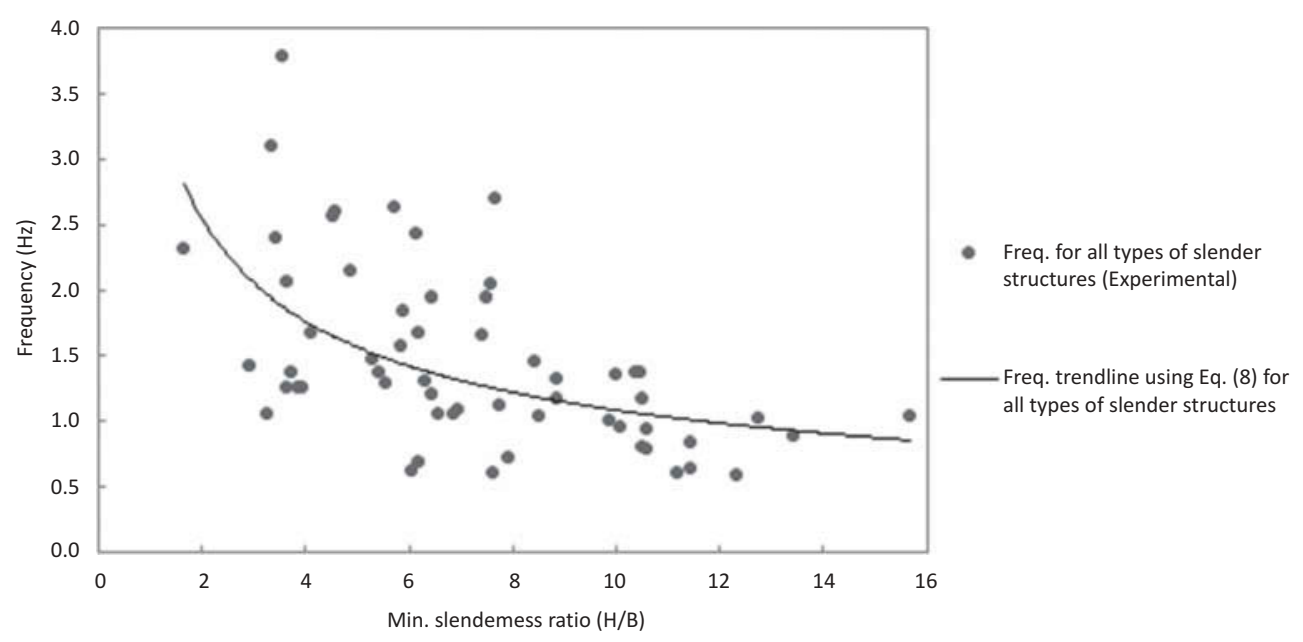

Figure 8. Comparison between experimental and predicted values of the fundamental frequency according to Equation (8) for all types of slender structures.

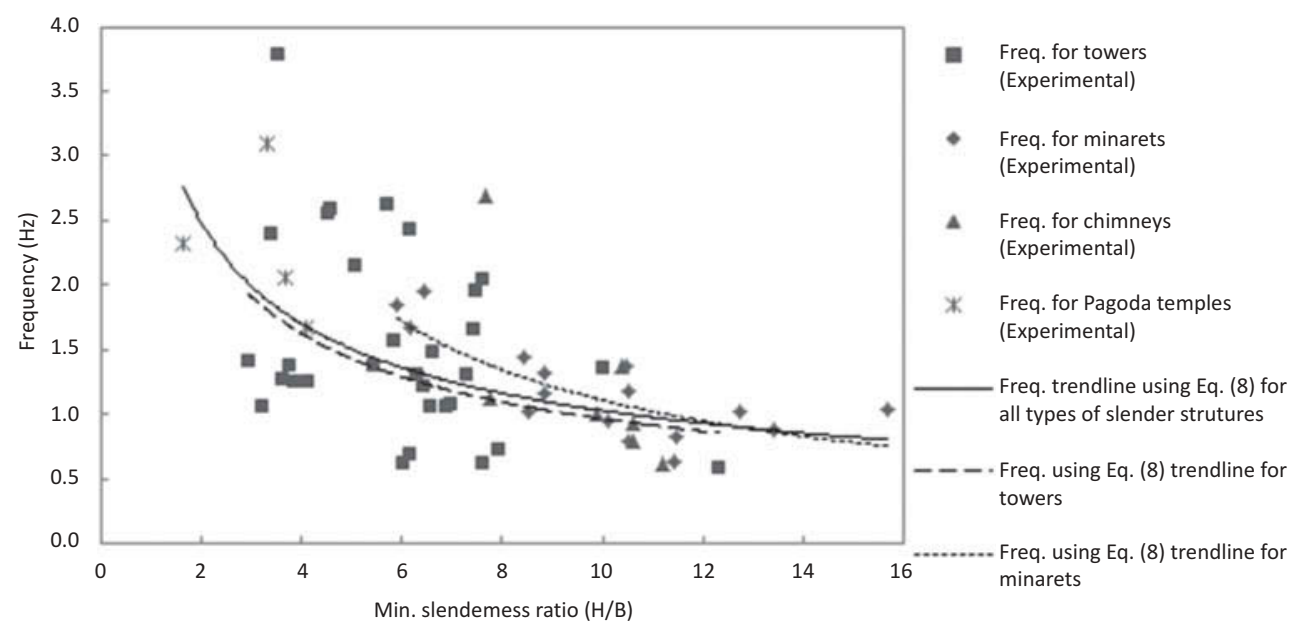

Figure 9. Comparison of the fundamental frequencies predicted by three different sub-formulations of Equation (8) for all types of slender masonry structures, towers and minarets.

structures. Data were collected through literature review on slender masonry structures regarding experimental natural frequency, geometrical and mechanical characteristics. The experimental fundamental frequencies have been correlated to develop an empirical formulation for the prediction of the fundamental frequency of slender masonry structures. Based on all documented and validated experimental data, reliable empirical formulations for the better prediction of the fundamental frequency for slender masonry structures are proposed. Comparative results confirm that the newly developed formulation has a reliable predictive performance.

\section{Funding}

The first author would like to express his gratitude to the scholarship under the Erasmus Mundus Action 2 Partnership, EU-NICE Project, supporting the research to develop within the PhD at University of Aveiro, Portugal.

\section{ORCID}

Aníbal Costa (1) http://orcid.org/0000-0001-8950-4843

\section{References}

Aoki, T., and D. Sabia. 2004. Theoretical and experimental analysis of brick chimneys, Tokoname, Japan. In Proceedings of the WCCM VI in Conjunction With APCOM'04, Computational Mechanics (September 5-10, 2004, Beijing, China). Beijing, China: Tsinghua University Press/Springer-Verlag.

Balduzzi, B., D. Mazza, D. Papis, C. Rossi, and P. P. Rossi. 2006. Experimental and numerical analysis for the strengthening intervention of the bell tower of St. Sistós Church in Bergamo. In Proceedings of the Structural Analysis of Historical Constructions (November 6-8, 2006, New Delhi, India).

Bartoli, G., M. Betti, and S. Giordano. 2013. In situ static and dynamic investigations on the "Torre Grossa" masonry tower. Engineering Structures 52:718-733. 
Bayraktar, A., T. Türker, B. Sevım, A. C. Altunisik, and F. Yildirim, F. 2009. Modal parameter identification of Hagia Sophia bell-tower via ambient vibration test. Journal of Nondestructive Evaluation 28:37-47.

Bennati, S., L. Nardini, and W. Salvatore. 2005a. Dynamic behaviour of a medieval masonry bell tower. Part I: Bell dynamic action measurement and modeling. Journal of Structural Engineering (ASCE) 131(11):1647-1655.

Bennati, S., L. Nardini, and W. Salvatore. 2005b. Dynamic behaviour of a medieval masonry bell tower. Part II: Measurement and modelling of the tower motion. Journal of Structural Engineering (ASCE) 131(11):16561664.

Bonato, P., Ceravolo, R., Stefano, A., and Molinari, F. 2000. Cross-time frequency techniques for the identification of Masonry buildings. Journal of Mechanical Systems and Signal Processing 14:91-109.

Bongiovanni, G., P. Clemente, and G. Buffarini. 2000. Analysis of the seismic response of a damaged masonry bell tower. In Proceedings of the 12th World Conference on Earthquake Engineering, Auckland, New Zealand, January 30-February 4, 2000.

Buffarini, G., P. Clemente, G. P. Cimellaro, and A. De Stefano. 2011. Experimental dynamic analysis of Palazzo Margherita in L'Aquila after the April 6th, 2009, Earthquake. In Proceedings of Experimental Vibration Analysis for Civil Engineering Structures (EVACES) (October 3-5, 2011, Varenna, Italy), 247-254.

Camata, G., L. Cifelli, E. Spacone, J. Conte, and P. Torrese. 2008. Safety analysis of the bell tower of S. Maria Maggiore Cathedral in Guardiagrele (Italy). In Proceedings of the 14th World Conference on Earthquake Engineering, Beijing, China, October 12-17, 2008.

Carone, A. S., D. Foti, N. I. Giannoccaro, and R. Nobile. 2013. Non-destructive characterization and dynamic identification of an historical bell tower. In Proceedings of the 4th International Conference on Integrity, Reliability and Failure. (June 23-27, 2013, Funchal/Madeira, Spain), paper no. 3988.

Casciati, S., and R. Al-Saleh, 2010. Dynamic behavior of a masonry civic belfry under operational conditions. Journal of Acta Mechanica 215:211-224.

Casolo, S., and F. Pena. 2007. Dynamics of slender masonry towers considering hysteretic behavior and damage. In Proceedings of the ECCOMAS Thematic Conference on Computational Methods in Structural Dynamics and Earthquake Engineering, ed. M. Papadrakakis, D. C. Charmpis, N. D. Lagaros, and Y. Tsompanakis, (June 13-16, 2007, Rethymno, Crete, Greece), 1-12.

Casolo, S., G. Milani, Uva, and C. Alessandri. 2012. Comparative seismic vulnerability analysis on ten masonry towers in the coastal Po Valley in Italy. Engineering Structures 49:465-490.

Ceriott, M., I. Mottola, G. P. Picco, A. L. Murphy, S. Guna, M. Corra, et al. 2009. Monitoring heritage buildings with wireless sensor networks: The Torre Aquila deployment. In Proceeding of the 8th International Conference on Information Processing in Sensor Networks (IPSN) (April 13-16, 2009, San Francisco, CA), 277-288.

Ceroni, F., M. Pecce, and G. Manfredi. 2010. Seismic Assessment of the bell tower of Santa Maria Del Carmine: Problems and solutions. Journal of Earthquake Engineering 14:30-56.
Clough, R. W., and J. Penzien, 1993. Dynamics of Structures (2nd ed.) McGraw-Hill Book Company, New York.

Corradi, M., Borri, A., and Vignoli, A. 2002. Strengthening techniques tested on masonry structures struck by the Umbrian-Marche earthquake of 1997-1998. Journal of Construction and Building Materials 16(4):229-239.

Costa, A. 2010. Relatorio de inspeccao de uma chamine sita em vila Franca de xira, relatorio tecnico. Paço de Arcos, Portugal: Projecto e Fiscalização, Lda

Costa, A. 2011. Ambient vibration measurement of bell tower. Porto, Portugal: University of Aveiro.

Costa, A., J. Guedes, B. Silva, and V. Lopes. 2011. Inspeccao diagnostic e caracterizacao material-Chamine em matosinhos. Relatório Técnico do Georreferenciamento.

Curti, E., S. Lagomarsino, and S. Podestà. 2006. Dynamic models for the seismic analysis of ancient bell towers. In Proceedings of the 5th of the International Conference on Structural Analysis of Historical Constructions (SAHC), ed. P. B. Lourenço, P. Roca, C. Modena, and S. Agrawal (November 6-8, 2006, New Delhi, India). Porto, Portugal: University of Porto.

Curti, E., S. Parodi, and S. Podesta. 2008. Simplified models for seismic vulnerability analysis of bell towers. In Proceedings of the 6th International Conference on Structural Analysis of Historical Constructions (SAHC) (July 2-4, 2008, Bath, UK).

D’Ambrisi, A., V. Mariani, and M. Mezzi. 2012. Seismic assessment of a historical masonry tower with nonlinear static and dynamic analysis tuned on ambient vibration tests. Engineering Structures 36:210-219.

Diaferio, M., D. Foti, N. I. Giannoccaro, and M. Vitti. 2013. On the use of modal analysis and ground penetrating radar test for the physical parameter identification of an historical bell tower. In Proceedings of the Vienna Congress on Recent Advances in Earthquake Engineering and Structural Dynamics (VEESD) (August 28-30, 2013, Vienna, Austria), paper no. 560.

Dogangun, A., R. Acar, H. Sezen, and R. Livaoglu. 2008. Investigation of dynamic response of minaret structures. Bulletin of Earthquake Engineering 6:505-517.

El-Attar, A. G., A. M. Saleh, and A. H. Zaghw. 2005. Conservation of a slender historical Mamluk-style minaret by passive control technique. Journal of Structural Control and Health Monitoring 12:157-77.

Eusani, F., and F. Benedettini. 2009. Modal and structural identification of a masonry chimney. In Proceedings of the 19th Congress of Italian Association for Theoretical and Applied Mechanics (September 14-17, 2009, Ancona, Italy).

Faccio, P., S. Podestà, and A. Saetta. 2009. Venezia, Campanile della Chiesa di Sant'Antonin, Esempio 5. In Linee guida per la valutazione e riduzione del Rischio Sismico del Patrimonio Culturale Allineate alle Nuove. Norme Tecniche per le Costruzioni (DM 14/01/2008).

Ferraioli, M., A. Mandara, D. Abruzzese, and L. Miccoli. 2011. Dynamic identification and seismic safety of masonry bell towers. In Proceedings of the 14th Conference of Associazione Nazionale Italiana di Ingegneria Sismica (ANIDIS) (September 18-22, 2011, Bari, Italy).

Firat, Y. G. 2001. A study of the structure response of minarets in 1999 Anatolian earthquakes. Master's Thesis, Purdue University. 
Foti, D., S. I. Chorro, and M. F. Sabbà, 2012. Dynamic Investigation of an ancient masonry bell tower with operational modal analysis: A non-destructive experimental technique to obtain the dynamic characteristics of a structure. Open Construction and Building Technology Journal 6:384-391.

Gentile, C., and A. Sais. 2013.Operational modal testing of historic structures at different levels of excitation. Construction and Building Materials 48:1273-1285.

Gentile, C., and A. Saisi. 2007. Ambient vibration testing of historic masonry towers for structural identification and damage assessment. Journal of Construction and Building Materials 21:1311-1121.

Grande, R., and S. M. Açores. 2009. Relatório dos Ensaios Dinmicos de Vibraçao Ambiental e Avaliaçao de Segurança Estrutural Face à Acçao Sismica. Porto, Portugal: University of Porto.

Guerreiro, L., and J. Azevedo. 2001. Análise e reforço da torres do relógio da Horta, Faial. In Proceedings of the 5th Encontro National de Sismologia e Engenharia Sismica (October 24-27, 2001, Azores, Portugal), 639-650.

Ivorra, S., and J. R. Cervera. 2001. Analysis of the dynamic actions when bells are swinging on the bell tower of Bonreposi Mirambell Church (Valencia, Spain). In Proceedings of Historical Constructions 2001: Possibilities of Numerical and Experimental Techniques, ed. P. B. Lourenço and P. Roca (November 7-9, 2001, Guimarães, Portugal: University of Minho). Guimarães, Portugal: University of Minho.

Ivorra, S., and Pallares, F. J. 2006. Dynamic investigation on a masonry bell tower. Engineering Structures 28:660-67.

Ivorra, S., F. J. Pallares, J. M. Adam, and R. Tomas. 2010. An evaluation of the incidence of soil subsidence on the dynamic behavior of a Gothic bell tower. Engineering Structures 32:2318-2325.

Jaishi, B., B. X. Ren, Z. H. Zong, and P. N. Maskey. 2003. Dynamic and seismic performance of old multi-tiered temples in Nepal. Engineering Structures 25:1827-1839.

Jaras, A., R. Kliukas, and R. Kačianauskas. 2010. The dynamic loading of Vilnius arch cathedral belfry-Investigation and analysis. In Proceedings of Structures and Techniques: 10th International Conference on Modern Building Materials (May 19-21, 2010, Vilnius, Lithuania).

Kohan, P. H., Nallim, L. G., and Gea, S. B. 2011. Dynamic characterization of beam type structures: Analytical, numerical and experimental applications. Applied Acoustics, 72:975-981.

Krstevska, L., L. Tashkov, N. Naumovski, G. Florio, A. Formisano, A. Fornaro, et al. 2010a. In-situ experimental testing of four historical buildings damaged during the 2009 L'Aquila earthquake. In Proceedings of COST Action C26: Final Conference "Urban Habitat Constructions Under Catastrophic Events”, ed. F. M. Mazzolani (September 1618, 2010, Naples, Italy). London, UK: CRC Press, 427-432.

Krstevska, L., L. Tashkov, K. K. Gramatikov, R. Landolfo, O. Mammana, F. Portioli, et al. 2010b. Large-scale experimental investigation on Mustafa Pasha Mosque. Journal of Earthquake Engineering 14:842-73.

Lermitte, S. J., E. Fournely, T. Lamadon, and N. Juraszek. 2011. Learning from the post-earthquake mission following the L'Aquila earthquake. Bulletin de la Societe Geologique de France 182(4):381-388.

Lopes, V., J. M. Guedes, E. Paupério, A. Arêde, and A. Costa. 2009. Ambient vibration testing and seismic analysis of a masonry chimney. Journal of Building Appraisal 5(2):101-21.

Milani, G., S. Russo, M. Pizzolato, and A. Tralli. 2012. Seismic behavior of the San Pietro di Coppito Church Bell Tower in L'Aquila, Italy. Open Civil Engineering Journal 6(Suppl 1-M3):131-147.

Norma de Construcciòn Sismorresistente (NSCE [Spanish Standard]). 2002. NSCE-02: Norma de Construcciòn Sismorresistente-Parte General y Edificaciòn. Madrid: Spain, Ministerio de Fomento.

Oliveira, C. S., E. Cakti, D. Stengel, and M. Branco. 2012. Minaret behavior under earthquake loading: The case of historical Istanbul. Journal of Earthquake Engineering \& Structural Dynamics 41:19-39.

Pau, A., and F. Vestroni. 2011. Dynamic characterization of ancient masonry structures. Advances in Vibration Analysis Research 213-30.

Peeters, B., G. Sforza, L. Sbaraglia, and F. Germano. 2011. Efficient operational modal testing and analysis for design verification and restoration baseline assessment: Italian case studies. In Proceedings of Experimental Vibration Analysis for Civil Engineering Structures (EVACES) (October 3-5, 2011, Varenna, Italy).

Pelella, T., G. Mannara, E. Cosenza, I. Iervolino, and L. Lecce. 2001. Structural dynamic investigations on the bell tower from the S. Lucia's Church-Serra s. Quirico (Ancona). In Proceedings of the 7th International Seminar on Seismic Isolation, Passive Energy Dissipation and Active Control of Vibrations of Structures (October 2-5, 2001, Assisi, Italy).

Pieraccini, M., M. Fratini, D. Dei, and C. Atzeni. 2009. Structural testing of historical heritage site towers by microwave remote sensing. Journal of Cultural Heritage 10:174-82.

Rainieri, C., and G. Fabbrocin. 2011. Predictive correlations for the estimation of the elastic period of masonry towers. In Proceedings of Experimental Vibration Analysis for Civil Engineering Structures (EVACES) (October 3-5, 2011, Varenna, Italy), 513-520.

Ramos, L. F., L. Marques, P. B. Lourenco, G. Roeck, A. Campos-Costa, and J. Roque. 2010. Monitoring historical masonry structures with operational modal analysis: Two case studies. Mechanical Systems and Signal Processing 24:1291-1305.

Russo, G., O. Bergamon, L. Damiani, and D. Lugato. 2010. Experimental analysis of the "Saint Andrea" Masonry Bell Tower in Venice. A new method for the determination of "tower global Young's modulus E". Engineering Structures 32:353-60.

Salvatore, W., S. Bennti, and M. D. Maggiora. 2003. On the collapse of masonry tower subjected to Earthquake loadings. In Proceedings of the 8th International Conference on Structural Studies, Repairs and Maintenance of Heritage Architecture (May 7-9, 2003, Hakidiki, Greece).

Sepe, V., E. Speranza, and Viskovic, A. 2008. A method for large-scale vulnerability assessment of historic 
towers. Structural Control and Health Monitoring 15:389-415.

Shakya, M., H. Varum, R. Vicente, and A. Costa. 2014. Seismic sensitivity analysis of the common structural components of Nepalese Pagoda temples. Bulletin of Earthquake Engineering 12(4):1679-1703.

Tomaszewska, A. 2010. Influence of statistical errors on damage detection based on structural flexibility and mode shape curvature. Computers \& Structures 88:154-64.

Turk, A. M., and C. Cosgun. 2012. Seismic behaviour and retrofit of historic masonry minaret. Građevinar 1:39-45.
Yamamoto, T., and T. Maeda. 2008. Earthquake safety assessment of a tall brick chimney in Tokoname based on the micro-tremor measurement. In Proceedings of the 14th World Conference on Earthquake Engineering (October 12-17, 2008, Beijing, China).

Zaki, M. A., A. F. Hassan, S. A. Mourad, and A. M. Osman. 2008. Evaluation of the structural integrity of historical stone minarets. In Proceedings of the 14th World Conference on Earthquake Engineering (October 12-17, 2008, Beijing, China). 